\title{
The Distributional Effects of Trade on Austrian Wages ${ }^{1}$
}

To shed some light on the impact of the growing international division of labor on wages, this paper aims to assess the effect of trade on wage distribution in the Austrian manufacturing industry by estimating quantile wage regressions. In the regressions, we control for the share of imports and exports in the total production of industrial sectors and take into account the wage level of trading partners. A decomposition of wage changes from 1996 to 2002 shows that, while imports from low-wage countries had a dampening effect on manufacturing wages in Austria, wage growth was dampened above all by exports to high-wage countries. This could be interpreted as evidence for the "bazaar economy" hypothesis.

\section{Introduction}

Austrian exports and imports in general and cross-border trade with Central and Eastern European countries (CEECs) in particular have grown steadily in recent years. According to traditional trade theory, the gains from growing trade depend on the pattern of factor endowment in the involved economies and are not equally distributed among production factors. In a country achieving net gains from trade, the winners could in theory compensate the domestic losers; in real-world settings, such compensation arrangements are rather unusual, which may be one reason public opinion often expresses discontent about globalization.

This paper is aimed at assessing the effects of trade on wages in Austrian manufacturing sectors. To estimate the effects on wages of international trade with high-wage or low-wage countries, we first estimate Mincer-type wage regressions that include the share of imports and exports in total production. The disaggregation of the trade variables with respect to trading partners' wage levels allows us to analyze the effects of trade with high-wage and low-wage countries, respectively. In addition, we use quantile regressions to estimate wage equations, which we use to see whether the effects of trade are different over the Austrian wage distribution. In a second step, we decompose the changes in the wage distribution over time into effects of changes in determinants of the wage structure (e.g. changes in the import intensity of individual industries) and changes in the returns to these determinants (i.e. wage premiums). Again, we use quantile regressions to estimate different effects over the distribution.

The paper is structured as follows. Section 2 briefly reviews the related literature with special reference to research on the Austrian situation. In section 3, the data sources are described, with an emphasis on the European Structure of Earnings Survey (ESES), a restricted-access source, which has therefore not been used very often so far for economic analysis in Austria. The empirical results of the wage regressions and the decomposition exercise are presented in section 4; finally, section 5 provides some concluding remarks.

\footnotetext{
This paper was presented at the OeNB's Conference on European Economic Integration (CEEI) 2008, which focused on "The Integration of European Labor Markets" and took place in Vienna on November 17-18, 2008.

2 Oesterreichische Nationalbank, Foreign Research Division,wolfgang.pointner@oenb.at. The author would like to thank Alfred Stiglbauer, Julia Wörz (both OeNB) and two anonymous referees for valuable comments and Tamara Geisberger (Statistics Austria) for excellent cooperation on access to data from the European Structure of Earnings Survey. The views expressed are those of the author and not necessarily those of the Oesterreichische Nationalbank.
} 


\section{Trade Effects: Theoretical Background and Empirical Evidence}

\subsection{The Impact of Exports and Imports on Wages}

The impact of trade on the distribution of income is usually analyzed in the framework of the Stolper-Samuelson theorem, which states that trade-induced changes in relative demand for goods will also change the relative prices of the factors used in the production of those goods. As firms specialize on producing goods for which factors are more abundant within their home country than abroad, the relative domestic prices of those factors also rise. The Stolper-Samuelson theorem has been used to explain the distribution of factor incomes, i.e. labor wages and returns on capital, but it can also be applied to analyze wage differentials between high- and low-skilled labor.

With regard to the effects of trade on the distribution of wages, ${ }^{3}$ it is assumed that countries differ with respect to their relative abundance of high- and lowskilled labor. Increasing trade between two countries should therefore cause the relative wage of low- (high-)skilled workers in a country with an abundance of high- (low-)skilled labor to decline. As high-skilled workers are on average better paid than low-skilled ones, more trade implies a more unequal wage distribution in high-wage countries and a less unequal one in low-wage countries.

In its 2007 Employment Outlook, the OECD (2007) documents an increase in the inequality of earnings in most high-wage countries. The rise in inequality was attributable mostly to large increases at the top of the distribution, measured by the decile ratio of earnings ${ }^{4}$. Therefore, the OECD concluded that imports from low-skilled countries had not been the major cause for the increase in inequality in OECD member states, because those imports should have resulted in rising inequality at the lower end of the distribution. Here, it may be useful to remember that the Stolper-Samuelson theorem only discusses relative wage changes between high- and low-skilled workers, and clearly the relative wage for low-skilled labor is declining. Furthermore, the argument holds only for trade with those emerging economies where the skill level on average is far below the OECD average. This most likely cannot be applied to Austria's trade with CEECs, as there is no reason to assume that the average skill level in CEECs differs much from the Austrian standard, especially in exporting industries. According to the OECD's Education at a glance (2008), the share of working-age population having attained at least upper secondary education was higher in the Czech Republic $(90 \%)$, Estonia (88\%), Slovakia and Slovenia (82\%) than in Austria $(80 \%)$ in 2006.

Furthermore, an increase in the trade volume between high-wage and lowwage countries is not a precondition for putting pressure on the low-wage sector in rich countries. Freeman (1995) stressed that the mere possibility of imports might be sufficient to depress wage growth for less skilled workers in high-wage countries. Credible threats to shift production abroad may reduce the bargaining power of unions, so that wage growth might stall without an observable increase

\footnotetext{
3 The wage distribution we are interested in is the nation-wide distribution across all sectors and firms.

${ }_{4}$ Decile ratios compare the earnings at different deciles of the earnings distribution. The D9/D1 ratio can be decomposed into D9/D5 and D5/D1 ratios, which, when examined over time, allow us to trace changes in the distribution to changes below or above the median.
} 
in trade flows. But, as Borjas, Freeman and Katz (1997) correctly state, such a threat effect is difficult to measure empirically.

One way of assessing the impact of trade on labor demand is to compute the factor content of exports and imports and then identify the net labor content as excess demand. The labor content of imports corresponds to a shift from domestic to foreign labor inputs. Wood (1995) proposes a method for taking into account the differences in skill intensity in the production of export and import goods in differently endowed countries. Previous research implicitly assumed that firms in high-wage and low-wage countries use the same technologies and thus have the same input ratio of high-skilled to low-skilled labor. Yet as skill endowments and hence returns to skills differ between those countries, it is rather implausible that factors are used in identical proportions. According to Wood's calculations, the imports from low-wage countries are a substitute for substantial employment in high-wage countries, and the additional demand created by export opportunities is much too low to compensate for that. In contrast, when Borjas, Freeman and Katz (1997) estimated the impact of trade between the U.S.A. and low-wage countries on relative labor supplies of different skill groups and on the wages of low-skilled U.S. workers, they found such trade to explain less than $10 \%$ of the observed decline in the relative wage of low-skilled Americans. This result may reflect the relatively closed economy of the U.S.A., which is hardly comparable with many small open economies in Europe.

A particular problem in working with trade data is the level of aggregation. The more disaggregated the trade data are, the more homogeneous the units of the trade statistics will be. Therefore, the probability that different countries use similar factors to produce traded goods is higher with more disaggregated statistics. Krugman (2008) features an example of how aggregation can explain an apparent contradiction to conventional trade theory. According to U.S. trade statistics, more than $75 \%$ of imported computers and electronic products come from China and other low-wage countries. While computer manufacturing is generally presumed to require a high skill level, the production of some computers no longer requires very high skills, especially if the more skill-intensive parts of production can be imported from elsewhere. So one solution to this conundrum would be to use more detailed disaggregated data on trade and skill content, but clearly the statistics on wages available so far place a limit to that approach.

In recent years, the impact of trade with very low-wage countries like China and other emerging economies in Asia has received more attention, especially in the U.S.A. The OECD (2007) reports that the share of Chinese imports in total OECD imports roughly doubled from 4\% to 8\% between 1996 and 2004. Could the acceleration of such exports to high-wage countries have increased the effects of trade on the wages of low-skilled workers in OECD countries? One counterargument refers to specialization. If low- and high-wage countries are so highly specialized that they cease to produce the same goods, increasing trade will not hurt workers in either of the two sets of countries, as imports are no longer substitutes for domestic production. Of course, during the process of specialization, workers may become redundant, as their output is replaced by imported goods, but once the countries have reached different "cones of diversification," workers in high-wage countries are shielded from negative effects of trade on wages or employment. This may be a realistic assumption for trade between the U.S.A. and 
China, but between Austria and the CEECs, skill endowments and specialization patterns do not differ so much as to make production in different "cones of diversification" a very likely scenario.

Another source of rising inequality that is related to trade is outsourcing, the fragmentation of production processes which were previously performed within one firm into separate units traded across borders. Feenstra and Hanson (1996) have shown that such activities lead to increasing demand for skilled labor in high-wage countries and therefore make the wage distribution more unequal.

The effects of trade and FDI on the labor share in Europe have been analyzed by Breuss (2007) with separate panel regressions for old EU countries and CEECs. Both regressions include total net trade as an independent variable; in the case of EU countries, the equation also contains the trade share with CEECs and net FDI outflows to the rest of the world, whereas the equation for the CEECs contains the trade share with EU countries and FDI inflows. The results match theory only to some extent: For the EU countries, the regression coefficients coincide with theoretical expectations (i.e. all have negative signs), but for the CEECs, only net trade increases the labor share, whereas the EU's trade share significantly depresses the labor share, and FDI inflows are hardly significant.

\subsection{Trade Effects in Austria}

In an early attempt to assess the effects of trade between Austria and selected CEECs, ${ }^{5}$ Aiginger, Winter-Ebmer and Zweimüller (1996) estimated employment and wage effects of such trade for the period from 1988 to 1991. Based on a sample of $2 \%$ of manufacturing workers from the Austrian social security records, they found the unemployment risk to have declined on average in sectors which export goods to the CEECs but not to have changed significantly as a result of imports from the CEECs. The unemployment risk differs significantly with respect to age, earnings and the type of occupation (i.e. blue-collar versus white-collar jobs). Wage increases were lower for employees in sectors with higher import growth from CEECs than for employees with unchanged CEEC import shares. The export share, in contrast, had a significant positive effect, but its size was much smaller, so the net effect of trade with CEECs was negative for the period in question. Aiginger, Winter-Ebmer and Zweimüller (1996) thus find the aggregate effects of trade with CEECs to be negative, but not very strong, while at the same time acknowledging that trade between Austria and the CEECs was still at very low levels in the period they studied.

Using comparable wage data for the period 1991 to 1994, Hofer and Huber (2003) assess the effects of trade and migration on earnings in Austria. That period differs from the one analyzed by Aiginger, Winter-Ebmer and Zweimüller (1996), as the boom of German unification was over and 1993 was a recession year, which substantially depressed average export and import growth rates; trade with the CEECs was, however, less affected than overall trade. Hofer and Huber (2003) find negative effects of imports on wages and positive effects of exports, whereas their results for migration are not significant. 
The paper at hand tries to assess the impact of trade on wages in a more recent period. Earnings data are available for two years, 1996 and 2002, from the European Structure of Earnings Survey (ESES), a new and very accurate data source. Whereas the distributional effects of trade have generally been modeled so far by estimating different effects for blue-collar and white-collar employees, the differences in the effects of trade on wages are captured with quantile regressions in this paper. In addition, those effects are decomposed into changes of the trade pattern and changes in the returns to working in more or less trade-intensive sectors.

\section{Data Description}

Many data sets on wages or earnings typically face limitations. Data from household surveys suffer from a notorious reluctance of individuals to state their earnings correctly, or answer income-related questions at all. Administrative records are much more reliable, but the data sets are often truncated as a result of topcoding, ${ }^{6}$ e.g. data from social security records only contain wage levels up to the earnings cap for social security contributions.

The wage variables used in this paper are derived from the Austrian national branch of ESES, a structural survey on individual earnings harmonized EU-wide and compiled periodically in line with EU regulations. A substantial advantage of ESES over other earnings surveys is the fact that the questions on wages are answered by employers, and that earnings-related information is often matched with administrative data. ${ }^{7}$

ESES covers firms with more than nine employees in the private sector except agriculture, i.e. manufacturing, construction and market-based services (Austrian Statistical Classification of Economic Activities ÖNACE sections C through K). On the employers' side, it provides information on firm size, industry affiliation and regional location (at the NUTS 1 level) ${ }^{8}$. Data on employees reflect gender, age, education, tenure with the current employer, type of contract (full-time or part-time, temporary or permanent employment), type of occupation (ranging from managers to elementary occupations) or the type of collective agreement the employee is subject to. The survey provides information about employees' highest education degree according to the International Standard Classification of Education (ISCED) and according to the Austrian national grading system; this allows us to compute the mandatory years of education for each employee.

Most importantly, the data contain information on the gross earnings of employees and on various sources these earnings stem from, so we can discern between bonus payments or premiums and ordinary wages. As the number of hours worked is also included in the survey, we can compute alternative measures for hourly wages. We use a wage variable for average hourly earnings including

\footnotetext{
6 For example, the research by Aiginger, Winter-Ebmer and Zweimüller (1996) and by Hofer and Huber (2003) is subject to top-coding.

For a comprehensive overview on the Austrian branch of ESES, see Statistics Austria (2006).

$\&$ NUTS stands for nomenclature des unités territoriales statistiques, or Nomenclature of Territorial Statistical Units. The three NUTS 1 regions in Austria are: Eastern Austria (Vienna, Lower Austria and Burgenland), Southern Austria (Carinthia and Styria) and Western Austria (Upper Austria, Salzburg, Tyrol and Vorarlberg).
} 
overtime and shift premiums, regular bonus payments and full-rate paid absences. The 2002 wages are HICP-deflated to make them comparable with 1996 wages.

For this paper, the two ESES waves conducted in 1996 and 2002 were available, covering about 120,000 employees ${ }^{9}$ from 8,000 firms (1996) and 140,000 employees from 10,000 firms (2002). As the definitions of employment contracts suitable for inclusion in the survey were altered slightly between 1996 and 2002, we restricted the data for comparability reasons to those employees who had worked with their employer for the whole year and whose earnings were above a certain threshold. In addition, we excluded individuals with earnings below the first and above the $99^{\text {th }}$ percentile as well as apprentices and persons younger than 16 and older than 65.

Statistics Austria keeps the Austrian ESES data strictly confidential; after all, the data contain detailed information about the wages of more than 100,000 individuals. Therefore, the regressions were executed by Statistics Austria, with codes transmitted by the author.

The trade data used in this paper are derived from Eurostat's ComExt database on the intra- and extra-EU trade of all EU Member States. The traded goods are aggregated into consistent production sectors. Here, the 2-digit NACE classification was used, as the ESES data also contain that information and the 2-digit level was the most disaggregated level available. As the data are restricted to goods trade, they represent only the manufacturing sector. ${ }^{10}$ In appendix table A1, the distribution of employees over the manufacturing industries at the two-digit level in 1996 and 2002 is displayed.

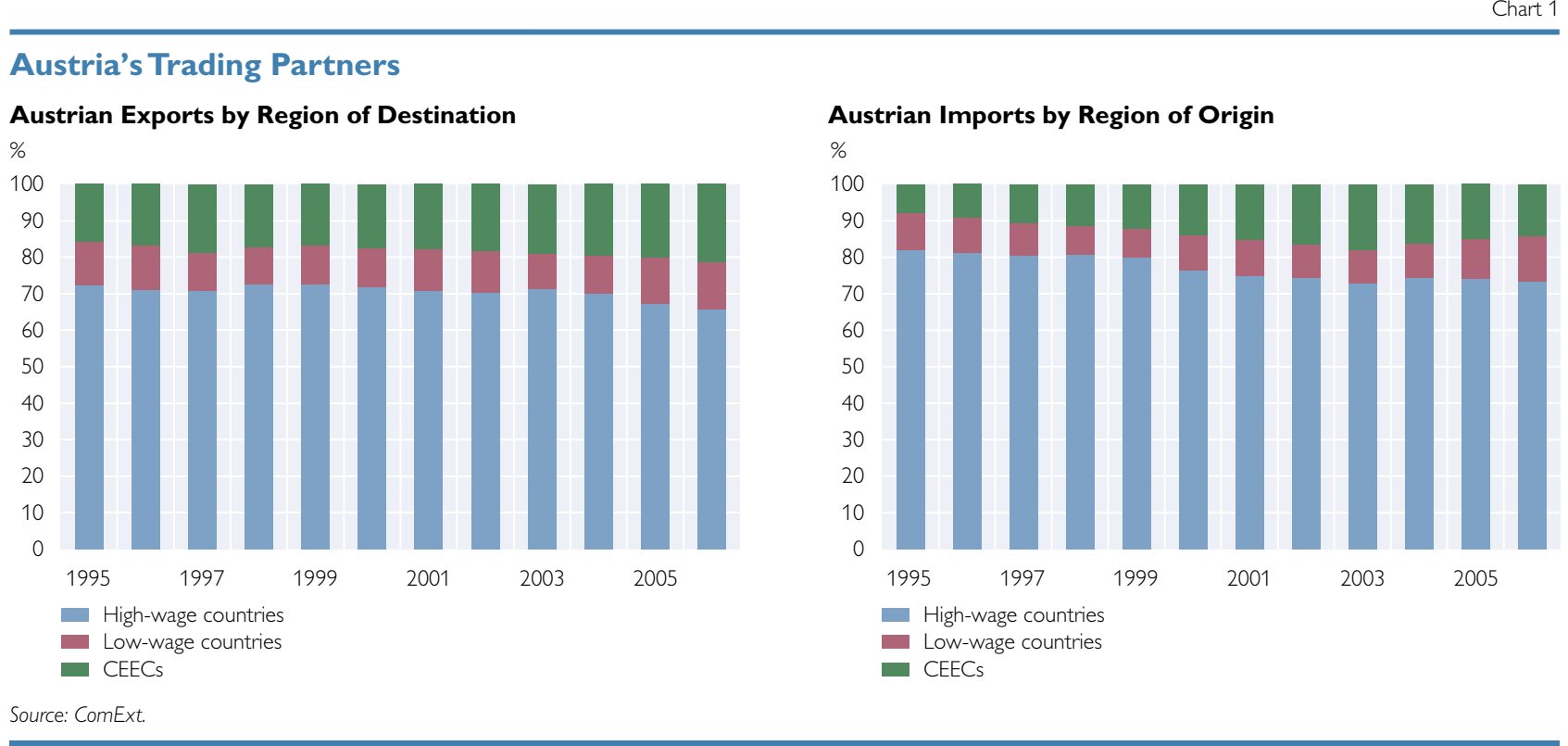

9 Strictly speaking, that number refers to jobs, so anyone holding two jobs in the survey period may appear twice in the data.

${ }^{10}$ For NACE sector 30 (Manufacture of office machinery and computers) the Austrian exports amounted to multiples of $100 \%$ of domestic production in 1996 and 2002. Presumably, the re-export of imports has been accounted for as exports in this sector, which is by definition not a manufacturing activity, but trade service. Therefore, this sector has been excluded from the analysis. 
For the purpose of this paper, the trading partners of Austria were aggregated in three groups: OECD countries except for new EU Member States, Korea, Turkey and Mexico are grouped together as "high-wage countries"; the countries that joined the EU in 2004 and 2007 together with the remaining Balkan countries, Belarus, Russia, Ukraine and Turkey form the "CEECs"; and the rest of the world is labeled "low-wage countries." As chart 1 shows, the vast majority of Austrian trade volumes are still exchanged with high-wage countries. The change in the share of CEECs in Austrian trade was relatively dynamic; from 1996 to 2002 the share in imports doubled from $8 \%$ to $16 \%$ and declined somewhat afterwards. Export shares were relatively stable over time, and the increase in the CEECs' share was smaller. For imports and for exports alike, the share of low-wage countries remained quite stable over time, causing the gains of the CEECs to result in a declining weight of high-wage countries in Austrian trade. But all in all, the variation over time is rather subdued.

Composition of Austrian Trade by Sectors

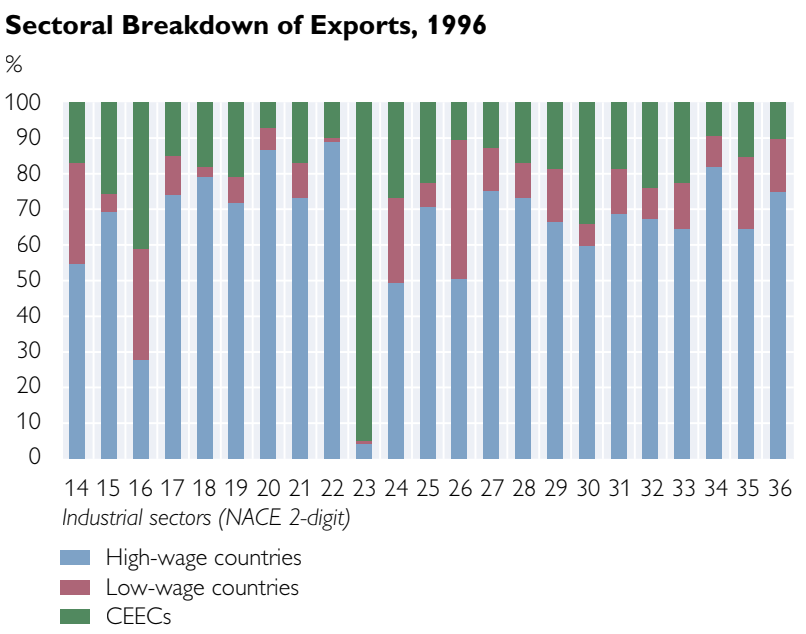

Sectoral Breakdown of Exports, 2002

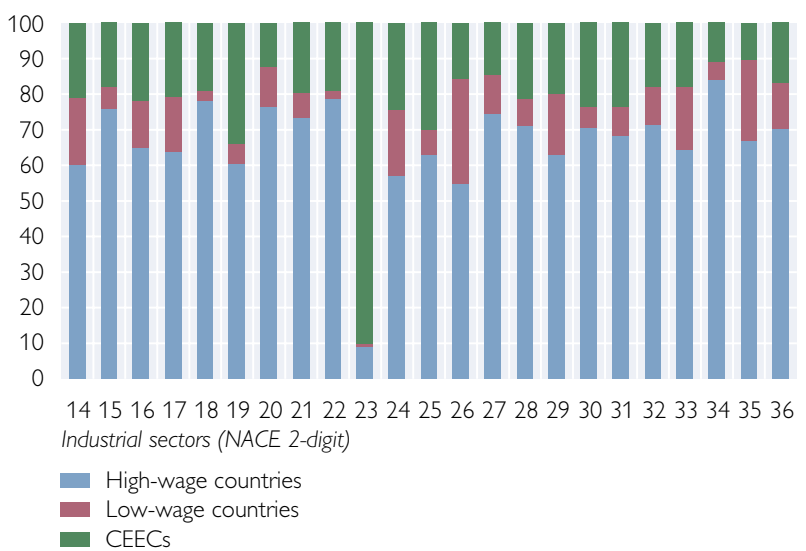

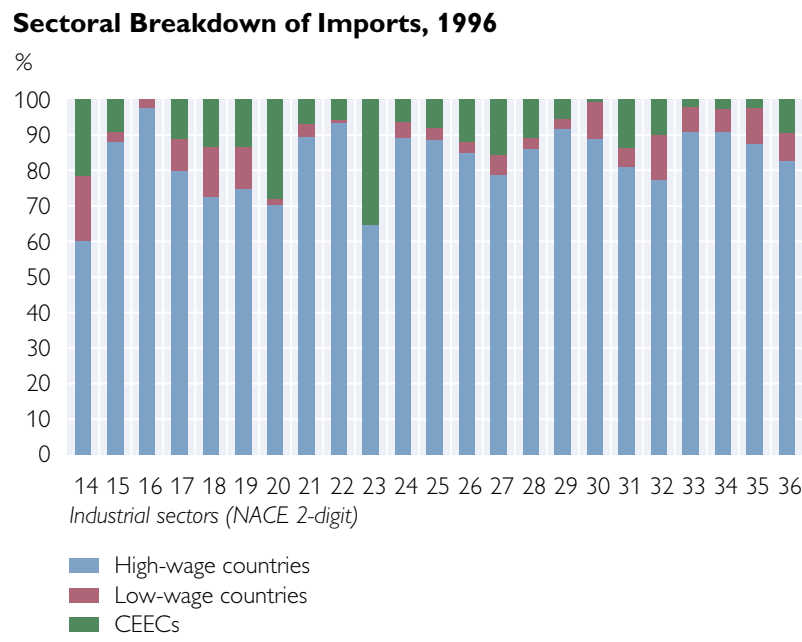

Sectoral Breakdown of Imports, 2002

$\%$

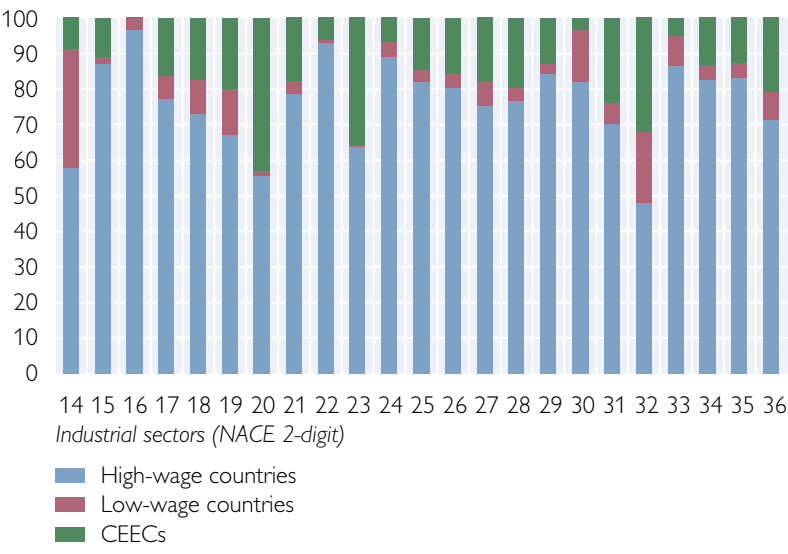



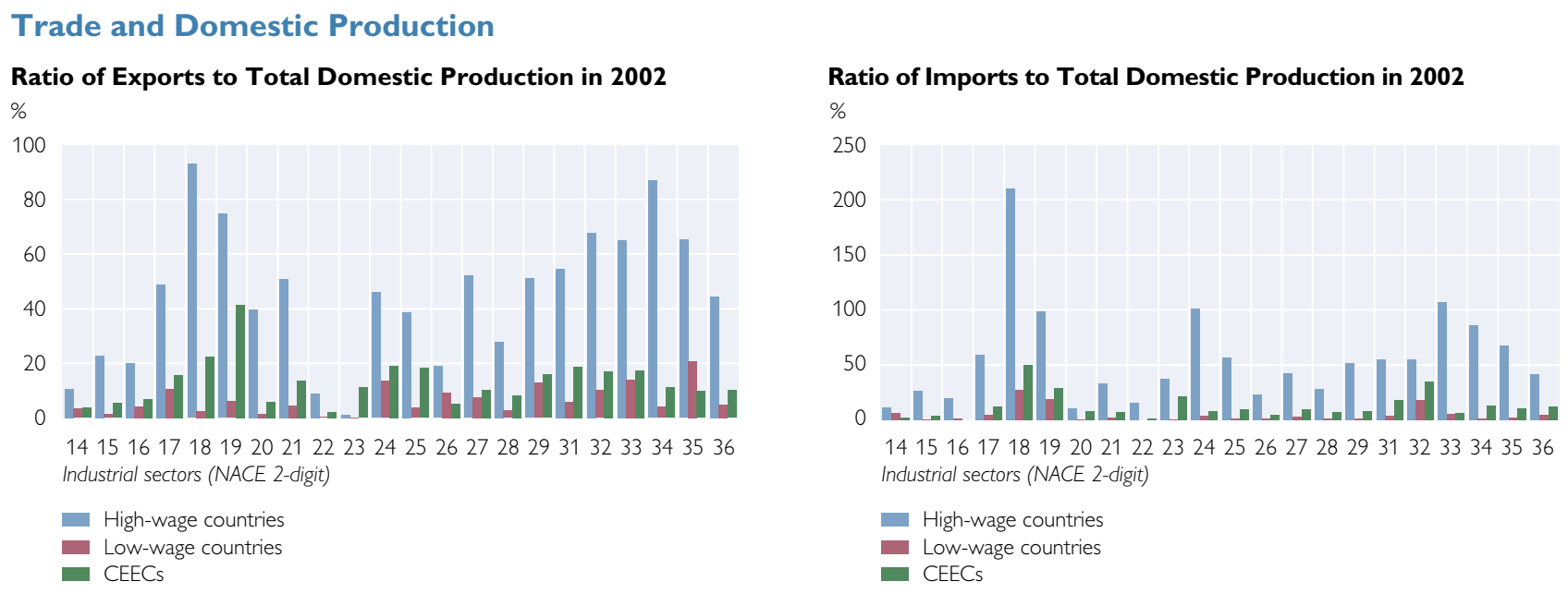

Source: ComExt.

At the sectoral level, the differences are more pronounced (see chart 2). For example, the CEEC shares in Austrian exports ranged from $95 \%$ to $7 \%$ and average $17 \%$ in 1996. The variation for imports is smaller, but still substantial. Based on trade flows at the sectoral level, the next step is to assess the effects of imports and exports on wages in Austria. In some sectors, exports to high-wage countries corresponded to $90 \%$ of domestic production, and imports of apparel even amounted to more than $200 \%$ of Austrian production (see chart 3). A list of the industrial sectors and their codes can be found in appendix table A1.

\section{Empirical Estimation of Trade Effects}

The wage distribution is determined by the qualitative composition of the workforce and the returns workers receive for different characteristics, such as returns to education. As high-skilled workers are usually better paid, a higher fraction of high-skilled workers will also drive up average wages. If demand for high-skilled workers goes up and supply is fixed in the short run, the returns to education will go up as well, thus changing the wage structure. Therefore, the data on wages derived from both ESES waves are first regressed on their main determinants to assess labor market returns such as skill premiums or wage premiums due to seniority. According to human capital theory, these main determinants are education and experience, but we also know that identical skills are not rewarded identically in different sectors or different regions within the same country.

As the returns to characteristics are not distributed evenly, quantile regressions are implemented to test for these differences. Sectoral trade variables are included to estimate the impact of imports and exports at different wage levels. Finally, the changes in the wage structure over time are calculated and decomposed into the effects of changes in the returns to characteristics like education or the trade intensity of industrial sectors (returns effect) and changes in the characteristics themselves (composition effect) between 1996 and 2002. 


\subsection{Results from Wage Regressions}

With the comprehensive ESES data on employees' characteristics, wage equations can be estimated to see whether the wage premium of education or tenure has changed. To estimate the effects of the explanatory variables on the wages of employees in different parts of the distribution, quantile regressions are used. In ordinary least squares (OLS) estimations, the coefficients represent the effects of the independent variables on the mean of the dependent variable. If, for example, we estimate the effect of years of schooling on wages, the OLS coefficient on education is 0.066 . This coefficient assumes that the effect of education is the same for all quantiles of the distribution.

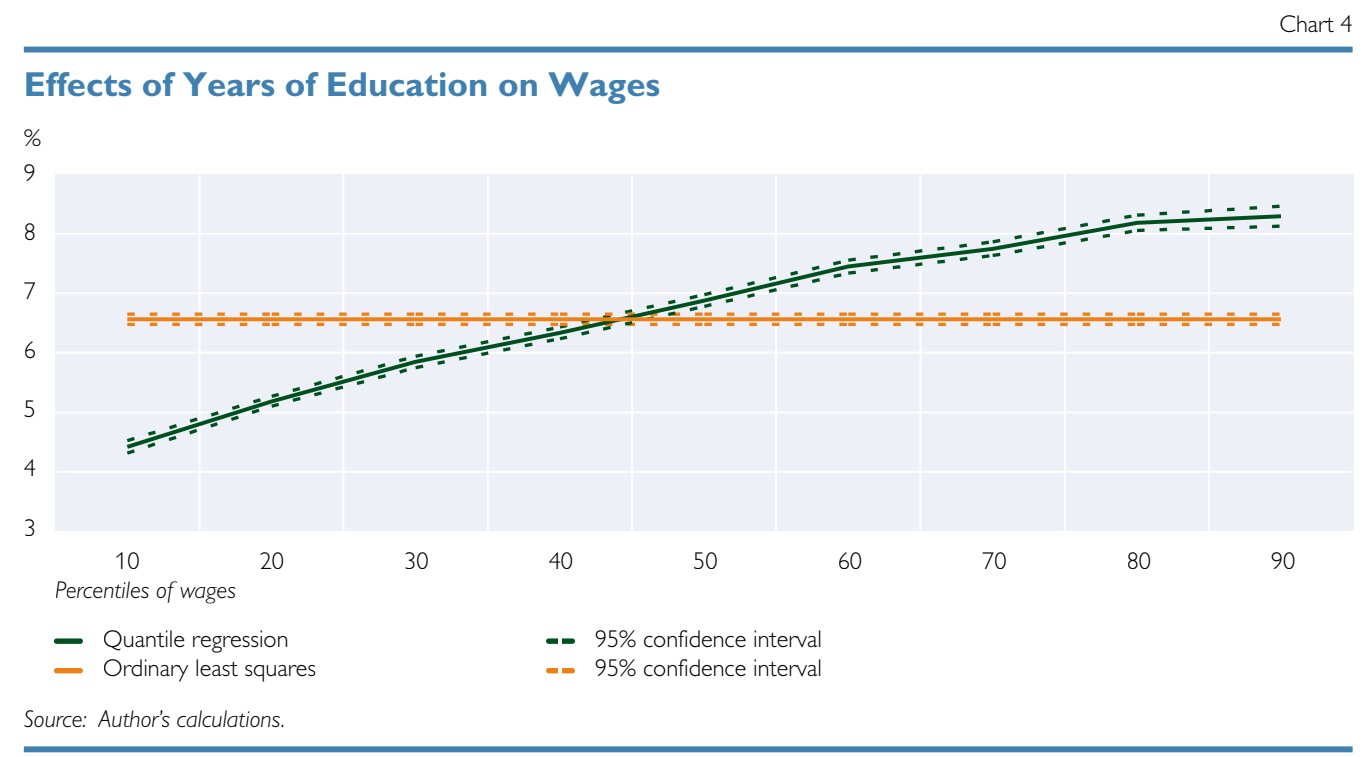

As chart 4 shows, the coefficients from quantile regression offer a different view. The effects of an additional year of education on wages grow along the distribution, and the estimated coefficients are mostly significantly different from the OLS estimation, as the 95\% confidence intervals around the estimated coefficients, indicated by the dashed lines, show. Therefore, the use of quantile regressions seems warranted in estimating the effects of trade on the wage structure, as they provide a better picture of the conditional distribution than do OLS estimations (see Koenker and Hallok, 2001).

In contrast to OLS estimations, quantile regressions are based on least absolute deviations (LAD) estimators. A simple quantile regression model of wage $\omega$ is given by

$$
\omega_{i}=z_{i} \beta_{\theta}+u_{\theta i} \text { with } Q_{\theta}\left(\omega_{i} \mid z_{i}\right)=z_{i}{ }^{\prime} \beta_{\theta}
$$

where $Q_{\theta}$ is the estimated $\theta^{\text {th }}$ quantile of $\omega$ conditional on the data set $z$, which contains information on employees' and firms' characteristics. The $\theta^{\text {th }}$ regression quantile is defined within a range from 0 to 1 as a solution to the problem

$$
\min _{\beta} \sum_{i} \rho_{\theta}\left(\omega_{i}-z_{i} \beta_{\theta}\right)
$$


with the function $\rho_{\theta}\left(\omega_{\mathrm{i}}-z_{i} \beta_{\theta}\right)$ assuming values of $2 \theta\left(\omega_{\mathrm{i}}-z_{i} \beta_{\theta}\right)$ if $\left(\omega_{\mathrm{i}}-z_{i} \beta_{\theta}\right) \geq 0$ and $2(1-\theta)\left(\omega_{\mathrm{i}}-z_{i} \beta_{\theta}\right)$ if $\left(\omega_{\mathrm{i}}-z_{i} \beta_{\theta}\right)<0$. If, for example the conditional median is to be estimated, $\theta$ equals 0.5 and $\beta$ is chosen so as to minimize the identically weighted residuals, i.e. the deviations of observed $\omega$ from $z_{i} \beta_{\theta}$. If we were interested in the $75^{\text {th }}$ quantile, the weights are not identical, but equal to 1.5 for positive residuals and 0.5 for negative ones. A useful feature of quantile regressions is their robustness to the problem of heteroscedasticity, which is often found in the analysis of wages. Typically, the variance of wages increases with education, which causes the OLS estimator to be inefficient. Quantile regressions take the possibility of changing variance into account, as they separately estimate the relation between dependent and independent variables for different points in the distribution and not just the conditional mean as the OLS estimator.

To assess the effects of employees' characteristics on the wage structure, wage regressions are estimated in OLS and in a quantile regression specification. In the literature, log wages are usually regressed on educational variables, age, age squared, experience, experience squared and a gender dummy. The ESES data contain information on highest completed education, from which the minimum years of formal education can be computed. This variable is labeled yedu. The age variable measures the age of employees, and ten the years of employment at the current employer (tenure). The variable ten is used as a proxy for firm-specific experience, and the age variable captures general work experience. The squared values of both variables are included because their marginal effect on wages is assumed to decrease; therefore, the coefficient on the squared values of age and ten is expected to be negative. Finally, we use a gender dummy, fem, which takes the value 1 for women and 0 for men.

$$
\ln \omega_{i}=\beta_{0}+\beta_{1} \text { yedu }_{i}+\beta_{2} \text { age }_{i}+\beta_{3} \text { age }_{i}^{2}+\beta_{4} \text { ten }_{i}+\beta_{5} \text { ten }_{1}^{2}+\beta_{6} \text { fem }
$$

Estimating this equation in OLS yields coefficients presented in the left panel of table 1 (specification 1). The effects of education are found to have been rather stable over time; the coefficient is nearly identical in both years at 0.067 , meaning that each additional year of schooling increases the hourly wage on average by $6.7 \%$. The effects of age and tenure declined significantly between the two survey years. Especially the return of general work experience as measured by age declined, which also means that the practice of paying higher wages due to seniority lost importance. The squared age and tenure variables are small and significantly negative, as expected (not shown in table 1). The female dummy shows an increase in the gender pay gap; controlling for education and experience, the wages of women employees were $22.4 \%$ lower on average than the wages of their male colleagues in 1996. The average gender pay gap increased by $2.5 \%$ in the six years to 2002. Although specification 1 is rather parsimonious in terms of independent variables, it already explains about $40 \%$ of the variation in wages.

In a second specification of the wage regression, more explanatory variables were included. The location of a firm may have an effect on the wage level; firms in urban agglomerations tend to pay higher wages. Unfortunately, the regional variable available from the ESES data is aggregated at the NUTS 1 level, so we can only distinguish three regions within Austria. The firm's size with respect to its number of employees also plays a role for wage levels; therefore, dummy variables 
for different size classes are included. And finally, to capture the impact of trade, the import and export shares of each industrial sector are added. The import (export) share is calculated as the ratio of imports (exports) of goods typically produced by that sector to the total output of that sector. If the independent variables of equation 3 are integrated in a set $\mathrm{X}$, the new regression is given by

$$
\ln \omega_{i}=\beta_{0}+X^{\prime} \beta_{1}+\beta_{2} \text { east }+\beta_{3} \text { south }+\sum_{j} \beta_{j} \text { size }_{i j}+\beta_{10} i m q+\beta_{11} \text { exq },
$$

where east and south are the two regional dummies for Eastern and Southern Austria and Western Austria is the reference category; size ${ }_{j}$ are dummies for the six different size classes, with firms with 25 or less as reference category; imq and exq are the import and export shares of industrial sectors. The central panel of table 1 shows the results of these regressions.

OLS Regression of Hourly Wages in 1996 and 2002

Variables

Constant

Education

Age in years

Tenure

Female

Eastern Austria

Southern Austria

Number of employees:

25-50

50-100

$100-250$

250-500

500-1,000

$>1,000$

Trade:

Import share

Export share

Shares of:

High-wage imports

Low-wage imports

CEEC imports

High-wage exports

Low-wage exports

CEEC exports

$\mathrm{R}^{2}$

Observations

\begin{tabular}{|c|c|c|c|c|c|}
\hline \multicolumn{2}{|l|}{ Specification 1} & \multicolumn{2}{|l|}{ Specification 2} & \multicolumn{2}{|l|}{ Specification 3} \\
\hline 1996 & 2002 & 1996 & 2002 & 1996 & 2002 \\
\hline $\begin{array}{r}0.9978 * * * * \\
0.06679 * * * \\
0.02243 * * * \\
0.01165 * * * \\
-0.22441 * * *\end{array}$ & $\begin{array}{r}1.3121 \text { **** } \\
0.06869 \text { **** } \\
0.00909 * * * \\
0.00923 * * * \\
-0.24955 \text { **** }\end{array}$ & $\begin{array}{r}1.02132 * * * \\
0.06708 * * * \\
0.0204 * * * \\
0.01106 * * * \\
-0.21394 * * * \\
0.0073 * * * \\
-0.04872 * * * \\
0.03542 * * * \\
0.05903 * * * \\
0.09955 * * * \\
0.14525 * * * \\
0.14748 * * * \\
0.21328 * * * \\
-0.07882 * * * \\
0.03133 * * *\end{array}$ & $\begin{array}{r}1.30723 * * * \\
0.06709 * * * \\
0.00833 * * * \\
0.00918 * * * \\
-0.23511 * * * \\
-0.08509 * * * \\
-0.01946 * * * \\
0.05306 * * * \\
0.1073 * * * \\
0.15889 * * * \\
0.18606 * * * \\
0.22279 * * * \\
0.27415 * * * \\
0.00264 \\
-0.09769 * * *\end{array}$ & 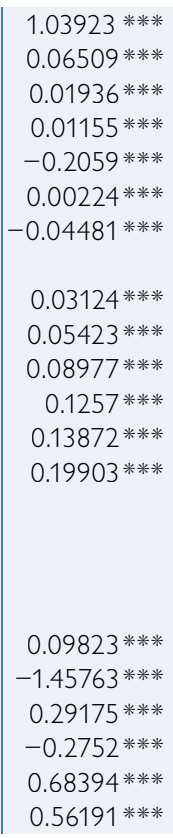 & 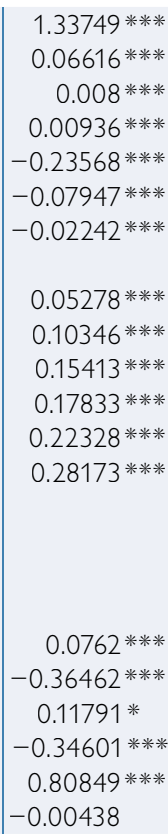 \\
\hline $\begin{array}{r}0.4 \\
45,367\end{array}$ & $\begin{array}{r}0.36 \\
29,325\end{array}$ & $\begin{array}{r}0.43 \\
45,367\end{array}$ & $\begin{array}{r}0.41 \\
29,325\end{array}$ & $\begin{array}{r}0.45 \\
45,367\end{array}$ & $\begin{array}{r}0.42 \\
29,325\end{array}$ \\
\hline
\end{tabular}

Source: Author's calculations.

Note: Dependent variable: log average hourly earnings include overtime, regular bonuses and full-rate paid absences.

* significant at 10\%; ** significant at 5\%; *** significant at $1 \%$.

The wages in the southern part of Austria (Styria and Carinthia) were significantly lower than in the western part (Upper Austria, Salzburg, Tyrol and Vorarlberg) in both years, with the relative gap declining, whereas in Eastern Austria (Vienna, Lower Austria and Burgenland) wages in manufacturing declined relative to the western part after 1996 and were $8.5 \%$ lower in 2002 . 
With respect to wages, we find that size matters. The size dummies all point to the expected relation, i.e. bigger firms pay higher wages. This effect intensified over time, with the coefficient on each size dummy being higher in 2002 than in 1996. Firms with more than 1,000 employees pay wages that are on average $21.3 \%$ (1996) or 27.4\% (2002) higher than the wages paid by firms with 25 employees or less.

The coefficients of the trade variables show the most pronounced changes over time. In 1996, the more goods typically produced by a sector were imported, the lower the wages of the employees in that sector. By 2002, however, this effect was not significantly different from zero. On the other hand, the positive impact of the export share in 1996 was reversed in 2002, when sectors with higher exportto-output ratios paid smaller hourly wages. However, it should be noted that the coefficients in both years, although statistically significant, are economically relatively small. The export shares are by definition bound between 0 and 1 , and most import shares also have values in that range. For example, if in 1996 the import share in sector $i$ was $10 \%$ higher than in sector $j$, according to the results in table 1 , this would translate ceteris paribus to a $0.7 \%$ lower wage in sector $i$.

To assess the impact of trade with different partners, we run the wage regressions again and split up the trade variables with respect to trade partners. Instead of using the share of all imports or all exports relative to output in each sector, imports are grouped according to countries of origin and exports according to countries of destination. As described in section 2, we pool Austria's trading partners in high-wage countries, low-wage countries and CEECs and calculate imports from and exports to them as shares of sectors' output, i.e.

$$
\text { imq }_{k}=\frac{\sum_{i} \text { imports }_{i k}}{\sum_{i} \text { output }_{i}} \text { and exq }_{k}=\frac{\sum_{i} \text { exports }_{i k}}{\sum_{i} \text { output }_{i}}
$$

for $k=$ high-wage countries, low-wage countries and CEECs.

So now all the independent variables from equation 4 except imq and exq are wrapped into $X$. We add some new explanatory variables: imhw stands for sector i's imports from high-wage countries relative to domestic production, imlw for sector i's imports from low-wage countries and imce for sector i's imports from CEECs; exhw, exlw and exce are the respective export shares. The new regression equation is given by

$$
\ln \omega_{i}=\beta_{0}+X^{\prime} \beta_{1}+\beta_{2} i m h w+\beta_{3} i m l w+\beta_{4} i m c e+\beta_{5} \text { exh } w+\beta_{6} \text { exlw }+\beta_{7} \text { exce }
$$

The results from estimating equation 6 are shown in the right panel of table 1 . The coefficients of trade with high-wage countries, which constitutes the largest share of Austrian trade, are comparatively stable over time. Sectors with more imports from high-wage countries on average paid higher wages in 1996 and 2002, but the effect declined over time. The division of labor with other high-wage countries seems to be productivity enhancing and therefore allows for higher wages.

Sectors with more imports from CEECs pay higher wages on average, which indicates low direct competition between domestic workers and foreign labor in those countries. Imports from CEECs are pronounced in the textiles and apparel 


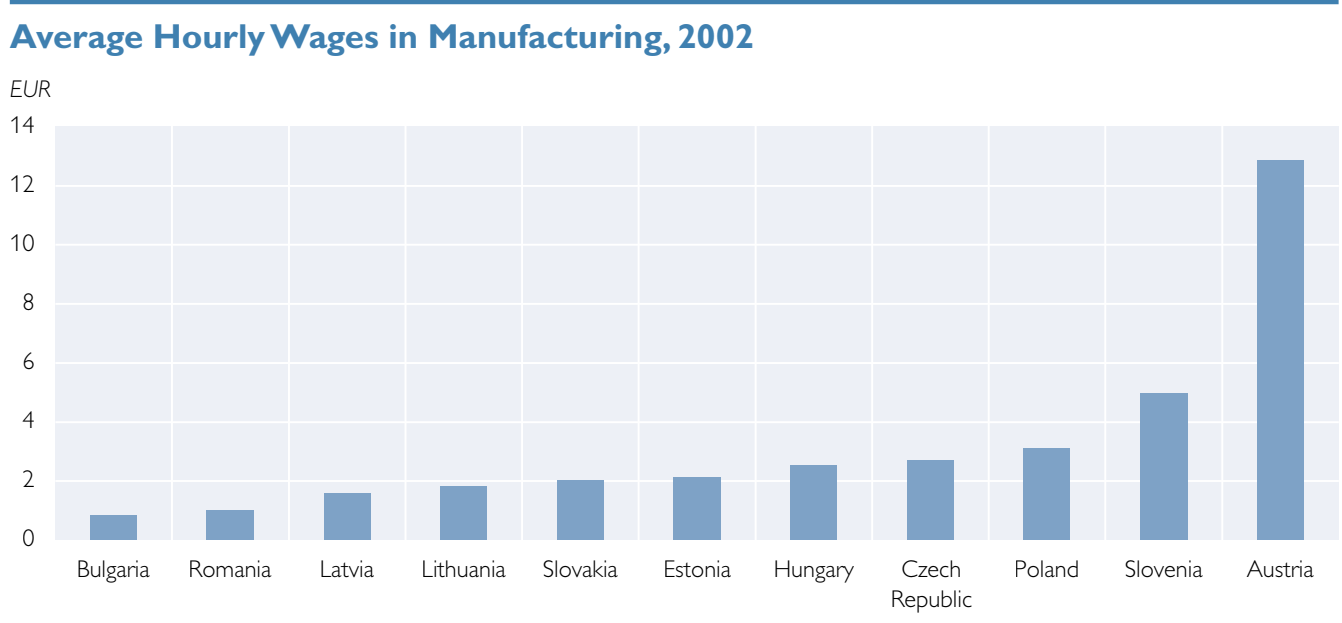

Source: Eurostat.

industries, and over time these imports also increased as a share of production. But the import share of that region in electronics, machinery and motor vehicles increased also between the two years. Although the skill levels in the CEECs do not differ so much from those in Austria, the average wage in manufacturing is much lower, as chart 5 shows. The depicted hourly wages for 2002 vary from 38\% to $6 \%$ of the Austrian wage level, measured at current exchange rates.

The effect of low-wage countries' imports was negative in both years, but lower in 2002 than in 1996. The biggest change in the import structure of low-wage countries in this period was the increase in imported communication equipment (NACE 32). With respect to the aggregation of imported goods in trade statistics, Krugman (2008) observed that data on such equipment - which is usually considered high-tech and skill-intensive production - are probably subject to data limitations. For example, the Chinese share in Austria's imported communication equipment increased from $1.6 \%$ in 1996 to $6 \%$ in 2002, while total imports in that sector from low-wage countries jumped from $4 \%$ to $21 \%$ of Austrian production. So if Chinese manufactures represent only the less skill-intensive stages in the production of communication equipment, they cannot serve as substitutes for Austrian products but rather provide cheaper inputs, which is why such imports would increase average sectoral productivity and raise wages.

The results for exports to different destinations indicate that exports to highwage countries depress the average wage. Here it should be noted that differences in skill levels are accounted for by the education and tenure variables. So if Austrian exports to high-wage countries are more skill-intensive than exports to low-wage countries and should therefore provide for higher wages, these effects are already captured by yedu and ten. Keeping that in mind, the negative coefficient of exports to high-wage countries could be interpreted as a sign that Austrian exporters have less market power in these markets, whereas in the low-wage countries and the CEECs, domestic firms have been able to demand higher markups. Whereas the effect of exports to low-wage countries increased over time, the positive impact of exporting to the CEECs has vanished. 
To explore the relation between trade and the distribution of wages, we run quantile regressions for 1996 and 2002 (tables on the quantile regressions for 1996 and 2002 for three different specifications are available from the author on request). In both years and in all specifications, the coefficient on yedu increases over the whole distribution except for the highest decile. In specification 1, the returns to education range from 0.045 to 0.084 in 1996, which means that an additional year of education would have increased the hourly wage for employees in the first decile by $4.5 \%$ and for employees in the $8^{\text {th }}$ decile by $8.4 \%$. As shown in chart 4 , the average effect calculated by OLS would be $6.6 \%$. For 2002, the returns to education are virtually the same as in 1996; the tiny differences are not significant. Martins and Pereira (2004) find the returns to education ${ }^{11}$ to be rather high in Austria compared to a sample of 16 OECD countries. Also, the difference between the $1^{\text {st }}$ and the $9^{\text {th }}$ decile is the second-largest in this group.

The returns to other characteristics are more evenly distributed, but changed more strongly over time. Interestingly, the gender bias is strongest around the median in both years. The coefficient on tenure was positive and rather stable over all deciles in 1996, which indicates that firm-specific human capital was valued at approximately the same rate for all wage levels. By 2002, the returns to tenure had decreased, especially for low-wage earners. The same holds for the returns to age, where coefficients were generally smaller in 2002 and were in particular below the median.

With regard to the trade variables, the impact of high-wage countries' imports on the wage distribution changed, as the effect was u-shaped in 1996, benefiting low- and high-wage earners more than employees with wages around the median. In 2002, the effect was positive for all deciles, but monotonously increasing in the wage level. So the benefits of imports from high-wage countries shifted from low-wage earners to middle-wage earners, with high-wage earners continuing to be the main beneficiaries. CEEC imports had positive effects on wages only for low-wage earners in both years; above the median, the effects are insignificant. The wage-diminishing impact of imports from low-wage countries was evenly distributed in 1996, but in 2002 the effect was less pronounced in the upper half of the distribution.

The exports to high-wage countries tended to dampen Austrian wages in both years, with the effect growing stronger for higher wages. In fact, the negative correlation of the effect with the wage level intensified over time. Working in an industry which exported to the CEECs was beneficial for wages in 1996, especially for middle-income earners; the coefficient of CEEC exports peaked around the median and was positive over the whole distribution. Yet by 2002, this positive effect of CEEC exports had dissipated; the coefficients were much smaller and insignificant. The estimated returns of exports to low-wage countries were significantly positive in both years, favoring Austrian low-wage earners in 1996 and appearing rather evenly allotted in 2002.

${ }^{11}$ Their specification includes years of schooling and experience as independent variables and they only used data on full-time working men; therefore, their results are not fully comparable to the findings of this paper, but they support our findings. 
The wage regressions tell us how given characteristics of the workforce, like education, gender or the import intensity of an industry, are valued in the Austrian labor market in each year. However, the wage structure is determined not only by the returns to these characteristics, but also by the distribution of these characteristics among the workforce. And as Freeman (1995) put it, "[...] no one can say with confidence what would have happened had imports from less-developed countries remained constant or at the same proportion of GDP over time." By decomposing the effects of changing wage premiums and changing characteristics of workers (e.g. changes of the trade intensity of the sectors they are employed in), we can proxy a counterfactual what-if analysis of wage changes in the way proposed by Freeman. The results of that exercise are presented in the next section.

\subsection{Decomposition of Changes in the Wage Distribution}

Real wage growth in the manufacturing sectors considered here was rather modest between 1996 and 2002. As depicted in chart 6, on average wages grew slightly more than $4 \%$, with faster growth in the upper half of the distribution. To explain concomitant changes in the wage distribution, we want to relate the distributional changes to changes in the composition of the workforce or the trade structure and changes of the compensation of different groups within the workforce. In doing so, we follow the counterfactual decomposition approach of Machado and Mata

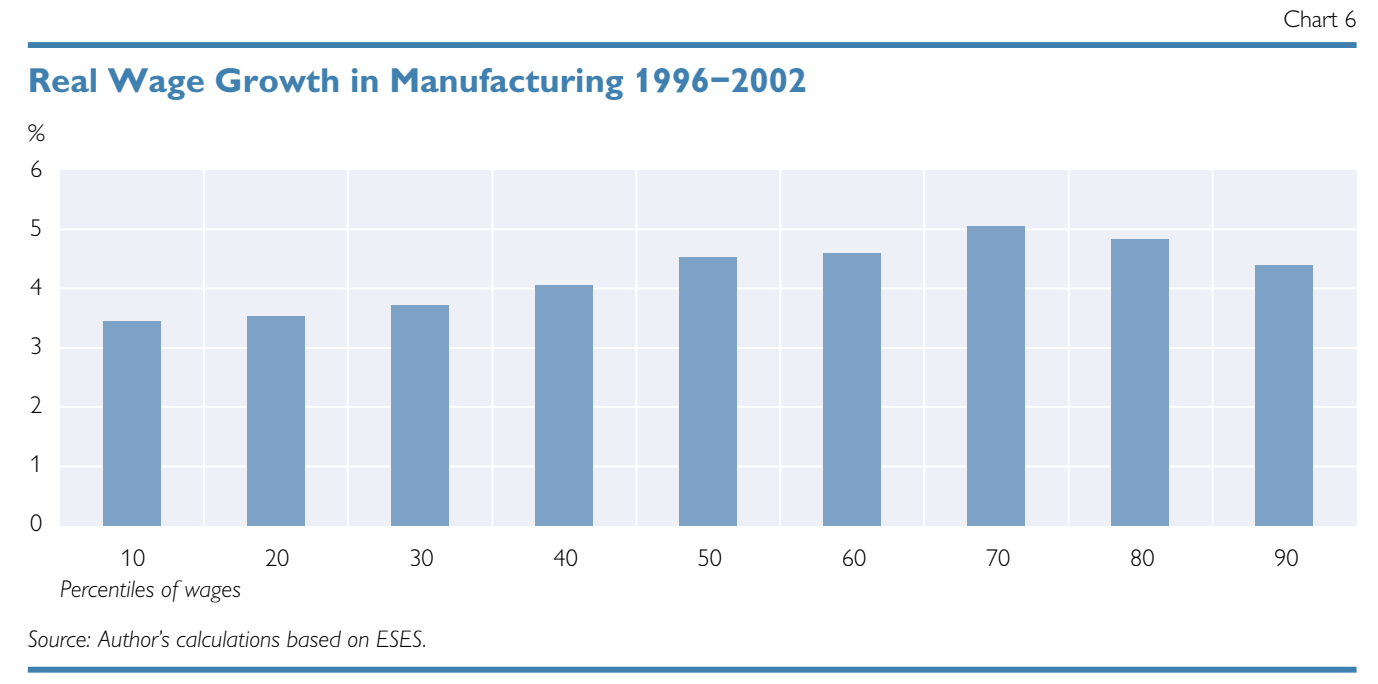

(2005). They extended the Oaxaca (1973) decomposition for the wage means on the whole distribution of wages by comparing the distribution of wages in a given year with a counterfactual distribution that would have prevailed if one or more explanatory variables had changed. Thereby, the effect of changes in single covariates on the wage distribution can be identified.

To decompose the wage changes between 1996 and 2002 to changes in characteristics $z$ or changes in the returns to those characteristics, which are given by the $\beta$ values of the wage regressions, we perform an application of the Machado and Mata (2005) decomposition developed by Albrecht, Björklund and Vroman (2003). Therefore, we compute the average characteristics of employees at each decile in both years by the following bootstrap procedure: 
1. A random sample of 100 observations is drawn (with replacement);

2. the drawn observations are ordered by wage, so that each observation represents one percentile of the wage distribution;

3. this procedure is repeated 500 times, providing the basis for the computation of averages for each decile.

The average characteristics computed by this procedure and the estimated coefficients from the quantile regressions allow us to decompose the recorded wage changes into changes of characteristics and changes of coefficients for each decile. The counterfactual decomposition starts from equation

$$
\ln \left(\omega_{\theta}^{2002}\right)-\ln \left(\omega_{\theta}^{1996}\right)=\bar{z}_{\theta}^{2002} \beta_{\theta}^{2002}-\bar{z}_{\theta}^{1996} \beta_{\theta}^{1996}
$$

with $\ln \left(\omega_{\theta}\right)$ being the log wage at the $\theta^{\text {th }}$ decile in the respective year, $\bar{z}_{\theta}$ the vector of average characteristics at the $\theta^{\text {th }}$ decile computed by the procedure described above, and $\beta_{\theta}$ the coefficients from the wage regressions.

Additionally, if we define

$$
\Delta \bar{z}_{\theta}=\bar{z}_{\theta}^{2002}-\bar{z}_{\theta}^{1996}
$$

and

$$
\Delta \beta_{\theta}=\beta_{\theta}^{2002}-\beta_{\theta}^{1996}
$$

we can rewrite equation 7 as

$$
\ln \left(\omega_{\theta}^{2002}\right)-\ln \left(\omega_{\theta}^{1996}\right)=\Delta \bar{z}_{\theta} \beta_{\theta}^{2002}-\bar{z}_{\theta}^{1996} \Delta \beta_{\theta}
$$

The first term on the right side gives us the effect of changed characteristics on the wage differential between the two years (composition effect); if only the characteristics of the employees had changed and the returns to these characteristics were the same in both years, that term would define the total wage change. The second term represents the impact of a change in the coefficients on the wage structure (returns effect). If the composition of the work force had been unaltered from 1996 on and only the returns to existing properties of the workforce had changed, we would end up with a wage change described by that term.

The results from this decomposition exercise can be seen in chart 7 . The effects of increasing exports to low-wage countries or CEECs is negligible, whereas the growing share of exports to high-wage countries in total manufacturing output depressed wage growth between 1996 and 2002. Also, the wage premium of working in a sector with a higher export share decreased over time, but the negative effect of working for a sector exporting to CEECs is even bigger than for one exporting to high-wage countries. Again, the effect of exports to low-wage countries is negligible. With respect to wage distribution, exports seem to reduce wage inequality, as the dampening effects on wage growth are higher for wages above the median than below.

These findings disagree with the studies on trade effects on Austrian wages cited in section 2.2, where exports mostly had a positive impact on wage growth. From factor content analysis, one would also expect that rising exports in a skill-intensive economy like Austria should raise demand for better educated (and better paid) employees and therefore raise wages on average.

At the same time, it should be noted that this analysis is based on total exports and total imports, including re-exported imports. A rising import content of 
exports is equivalent to a lower share of value added in exports ("bazaar economy"; see Sinn, 2005), which in turn means less scope for wage increases. The declining value added in exports has been the source of a discussion in Germany about the bazaar economy. For Austria, the input-output multiplier analysis by Bayerl et al. (2008) shows that value added in exports declined from 1995 to 2003, and this decline was more pronounced in manufacturing than in services. But they also find that export growth was sufficiently large to offset the smaller value added in exports. The negative effect of exports in the wage regressions represented in chart 7 indicates that the distribution of value added generated by export growth is skewed toward profits.

Another interpretation for the wage-dampening effects of exports would be that Austrian firms are trying to gain (or keep) export market shares by cutting wage costs. The negative composition effect of exports originates from growing exports to high-wage countries. These countries have similar factor endowments and produce similar goods, so competitive pressures for Austrian firms might be

\section{Decomposition of Effects on Wages}

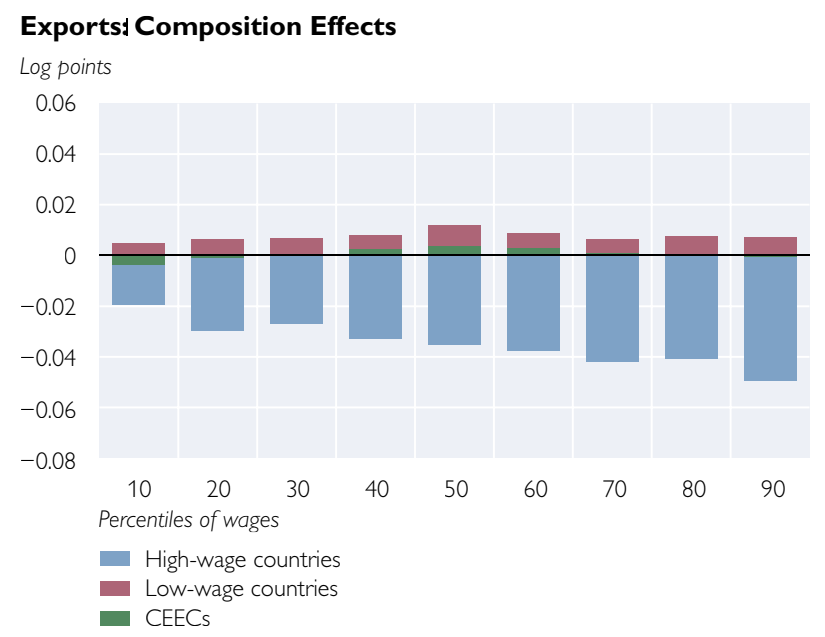

Imports: Composition Effects

Log points

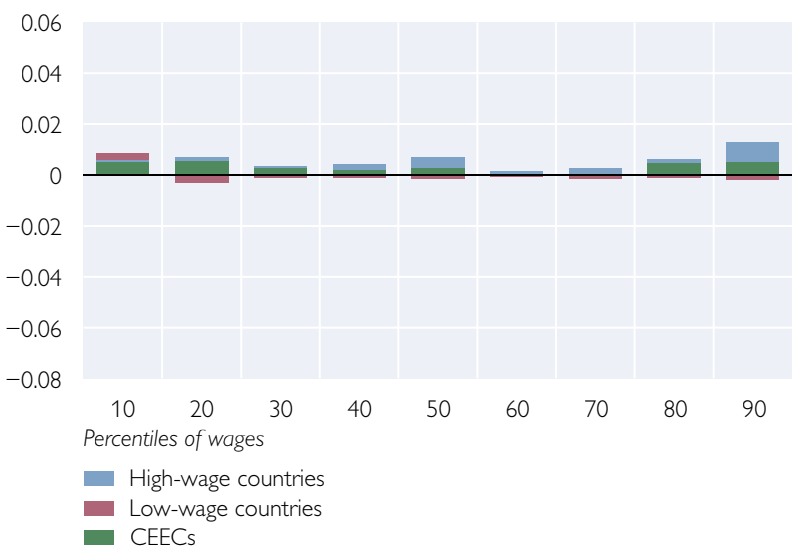

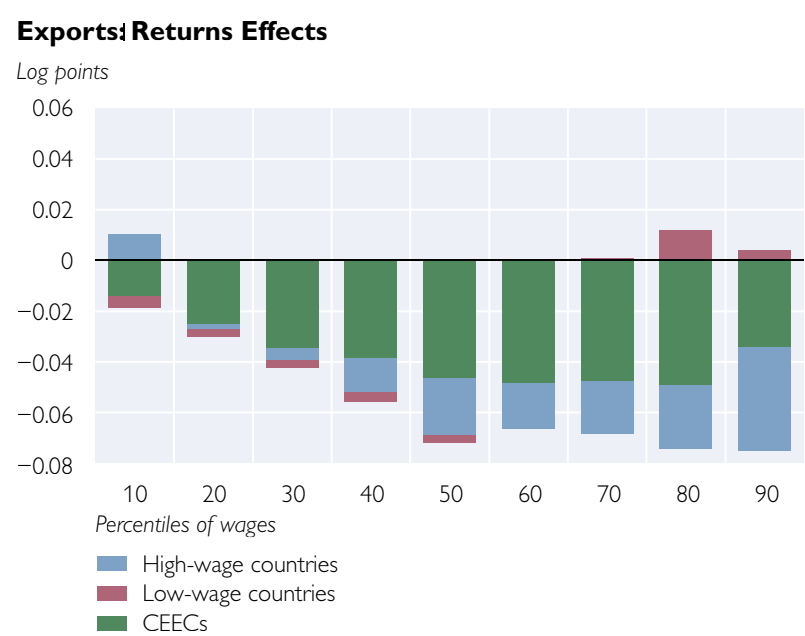

Imports: Returns Effects

Log points

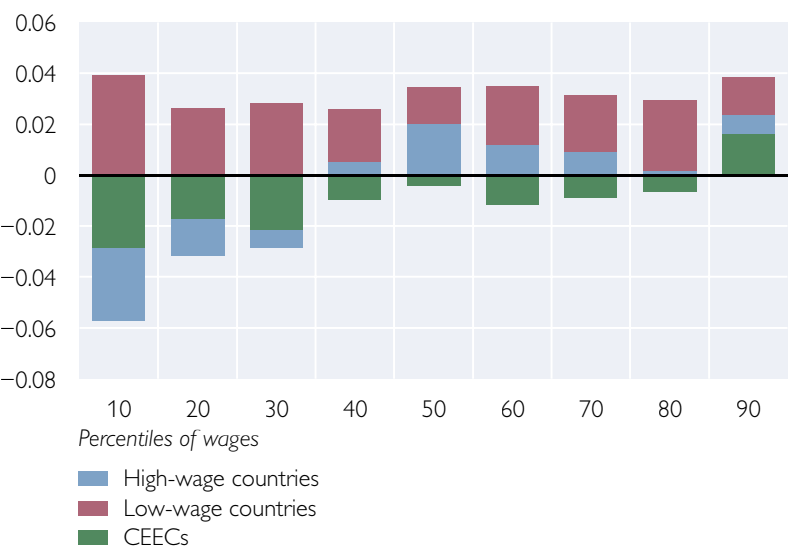


higher in these markets. Similarly, the reduction in the wage premium of sectors exporting to CEECs can be interpreted as declining price-setting power of Austrian firms. The decline in the returns to CEEC exports is stronger in the upper half of the distribution, because employees in these sectors received higher wage premiums in 1996. The returns of both exports to CEECs and high-wage countries had a more dampening effect on the wage growth of well-paid employees and therefore contributed to making wage inequality in Austria smaller.

As for imports, the composition effects are rather small and mostly positive, so the increasing share of imports actually contributed positively (if at all) to wage growth. The returns to working in a sector with imports from low-wage countries increased across the whole wage distribution, whereas imports from high-wage countries caused the wages of low-wage earners to fall and those of high-wage earners to grow. Sectors with more imports from CEECs also paid lower wages in 2002 than in 1996, and the negative effect was particularly pronounced for low-wage earners; for higher wages, the results are positive but not significant. Overall, the returns effect of imports contributed to an increase in wage inequality between 1996 and 2002, as high-wage earners benefited from imports, whereas the effects for low-wage earners mostly canceled each other out. Imports from high-wage countries and from CEECs might more often work as substitutes for domestic production, causing some crowding out, whereas imports from low-wage countries might serve as complements and therefore rather increase efficiency and wages. Interestingly, imports from CEECs are more similar in effect to imports from high-wage countries than from low-wage countries, which indicates that Austrian trade with CEECs does not fully match traditional StolperSamuelson models of different endowments.

From the decomposition analysis, we conclude that the effects of trade on Austrian wages have been twofold. Industries with higher exports tended to pay lower wages over the period under consideration. In particular, industries with higher exports to high-wage countries reduced their wages ceteris paribus. As about $70 \%$ of all Austrian exports go to high-wage countries, this effect prevails. The reason for the negative effect of exports could be found in fiercer competition for Austrian products on these markets and the increasing import content of exports (the "bazaar economy" phenomenon). In fact, the value added of Austrian exports declined from the mid-1990s to the early years of this decade, as evidenced by Bayerl et al. (2008). Considering the effect on wage distribution, exports tended to reduce inequality, as the effect on the deciles above the median was more negative. The distributional effects of imports point in the other direction, with wages above the median clearly benefiting from imports whereas, for lower wages, the effects of imports mostly canceled each other out, with low-wage countries' imports affecting wages positively and all other imports having negative effects. Neither the increase of CEEC imports relative to total production nor the increasing share of imports from CEECs seems to have affected Austrian wages in particular.

For the future some further research is warranted, especially about the reason for the wage-dampening effect of exports. It would be interesting to use more disaggregated firm data to see whether exports had a dampening effect on profits as well. It should also be noted that wage regressions on trade variables might be subject to an endogeneity bias, which could be overcome by instrumental 
variables (IV) estimation if proper instruments can be found and the IV estimation can be implemented with quantile regressions. Finally, the analysis should be repeated when the next ESES wave (surveying the wage structure in 2006) is available to assess whether the results are stable over a longer period.

\section{Summary and Conclusions}

Austrian trade in manufacturing has increased in recent years, as have the shares of imports and exports from and to CEECs. Increased imports from countries with a lower wage level have occasionally been identified as a reason for diminishing wage growth for low-wage earners in Austria. Traditional trade models would predict a decline of relative wages for less skilled workers when trade with laborabundant countries is growing.

Using firm survey data from the European Structure of Earnings Survey (ESES) in 1996 and 2002, we estimated wage regressions including trade variables to assess the impact of trade flows on Austrian wages. We find that manufacturing sector pay declines, the higher the imports of goods typically produced by these sectors from low-wage countries are. Sectors with more imports from high-wage countries or from CEECs pay higher wages on average. The effects work in reverse for exports. Sectors with more exports to low-wage countries pay higher wages and sectors with more exports to high-wage countries pay lower wages; exports to CEECs used to increase wages in 1996, but the effect had dissipated by 2002. The latter change could be interpreted as a result of catching-up, as the effect of CEECs as export markets became more similar to high-wage country effects.

We decomposed the effects of trade into a composition effect and a returns effect to analyze wage changes between 1996 and 2002. The rise in exports to high-wage countries dampened wage growth, and the wage premiums for exporting sectors declined as well, in particular for sectors exporting to high-wage countries or CEECs. This could be interpreted as evidence in favor of the "bazaar economy" hypothesis, which claims that a growing import content of exports reduces domestic value added generated by exports. Wage growth for employees in sectors importing from high-wage countries or CEECs has been reduced.

The changes in the wage distribution between 1996 and 2002 were slightly in favor of higher wage earners, but the contributions of trade to these changes were mostly in the opposite direction. The increasing exports to high-wage countries as well as negative changes in the wage premiums of exporting sectors dampened wage growth for high-wage earners more than for employees below the median. The effect of imports offset the leveling impact of exports somewhat, as the wage premiums for importing sectors declined more strongly for low-wage employees. According to our results, however, the increase in inequality cannot be attributed to the growing international division of labor. 


\section{References}

Aiginger, K., R. Winter-Ebmer and J. Zweimüller. 1996. Eastern European Trade and the Austrian Labor Market. In: Review of World Economics 132(3). 476-500.

Albrecht, J., A. Björklund and S. Vroman. 2003. Is There a Glass Ceiling in Sweden? In: Journal of Labor Economics 21(11). 145-177.

BayerI, N., O. Fritz, R. Hierländer and G. Streicher. (2008). Exports, Services and Value Added - A National, International and Regional Analysis for Austria. FIW Research Report 8.

Borjas, G., R. Freeman and L. Katz. 1997. How Much Do immigration and Trade Affect Labor Market Outcomes? Brookings Papers on Economic Activity 1. 1-90.

Breuss, F. 2007. Globalization, EU Enlargement and Income Distribution. WIFO Working Paper 296/07.

Freeman, R. 1995. Are Your Wages Set in Beijing? In: Journal of Economic Perspectives 9(3). $15-32$.

Feenstra, R. and G. Hanson. 1996. Globalization, Outsourcing, and Wage Inequality. In: American Economic Review 86(2). 240-245.

Hofer, H. and P. Huber. 2003. Wage and Mobility Effects of Trade and Migration on the Austrian Labour Market. In: Empirica 30(2). 107-125.

Izquierdo, M. and A. Lacuesta. 2006. Wage inequality in Spain: recent developments. Banco de España Working Paper 0615.

Koenker, R. and K. Hallok. 2001. Quantile Regression. In: Journal of Economic Perspectives 15(4). 143-156.

Krugman, P. 2008. Trade and Wages, Reconsidered. In: Brookings Papers on Economic Activity 1. 103-154.

Machado, J. and J. Mata (2005). Counterfactual decomposition of changes in wage distributions using quantile regression. In: Journal of Applied Econometrics 20. 445-465.

Martins, P. and P. Pereira. 2004. Does education reduce wage inequality? Quantile regression evidence from 16 countries. In: Labour Economics 11. 355-371.

Oaxaca, R. 1973. Male-Female Wage Differentials in Urban Labor Markets. In: International Economic Review 14(3). 693-709.

OECD. 2007. OECD workers in the global economy: increasingly vulnerable? Employment Outlook Chapter 3. 105-156.

OECD. 2008. To what level have adults studied? Education at a glance Chapter A. 28-51.

Sinn, H.-W. 2005. Die Basar-Ökonomie. Deutschland: Exportweltmeister oder Schlusslicht? Berlin: Econ Verlag.

Statistics Austria. 2006. Verdienststrukturerhebung 2002 Struktur und Verteilung der Verdienste in Österreich.

Wood, A. 1995. How Trade Hurt Unskilled Workers. In: Journal of Economic Perspectives 9(3). 57-80. 


\section{Appendix}

NACE Industrial Sectors and Their Share of Employees

\begin{tabular}{|c|c|c|c|}
\hline \multirow[t]{2}{*}{ ÖNACE } & Description & 1996 & 2002 \\
\hline & & $\%$ & \\
\hline NACE 14 & Mining and quarrying & 2.5 & 3.9 \\
\hline NACE 15 & Food products and beverages & 22.6 & 17.1 \\
\hline NACE 17 & Textiles & 5.3 & 5.0 \\
\hline NACE 18 & Apparel and furs & 2.3 & 3.1 \\
\hline NACE 19 & Leather, luggage, handbags & 1.6 & 1.8 \\
\hline NACE 20 & Wood and cork & 8.0 & 10.6 \\
\hline NACE 21 & Pulp and paper & 2.8 & 2.9 \\
\hline NACE 22 & Publishing and printing & 5.5 & 6.6 \\
\hline NACE 24 & Chemicals & 4.7 & 6.2 \\
\hline NACE 25 & Rubber and plastic & 6.2 & 5.8 \\
\hline NACE 26 & Other non-metallic mineral products & 4.2 & 5.0 \\
\hline NACE 27 & Basic metals & 2.2 & 8.7 \\
\hline NACE 28 & Fabricated metal products & 15.1 & 6.6 \\
\hline NACE 29 & Machinery and equipment & 5.8 & 5.9 \\
\hline NACE 31 & Electrical machinery and apparatus & 3.8 & 3.4 \\
\hline NACE 32 & Radio, television and communication equipment & 1.8 & 1.4 \\
\hline NACE 33 & Medical, precision and optical instruments & 2.2 & 2.8 \\
\hline NACE 34 & Motor vehicles & 2.4 & 1.0 \\
\hline NACE 35 & Other transport equipment & 0.8 & 1.9 \\
\hline Total & & 100 & 100 \\
\hline
\end{tabular}

